WIENER SLAVISTISCHES JAHRBUCH, Band 57/2011, 193-207

(C) 2011 by Österreichische Akademie der Wissenschaften, Wien

B E A T A TRA W IŃSK I

\title{
Theoretical and Empirical Aspects of Person, Number and Gender Resolution in Polish
}

\section{INTRODUCTION}

In this paper, I discuss some empirical aspects of person, number and gender resolution in Polish and propose principles that account for this phenomenon. The discussion is based on the resolution rules provided in Corbett 1983, 1991, 2000. I demonstrate that these rules require some revision in light of a number of empirical facts about Polish, and point out parallels regarding person, number and gender resolution between nominal coordination, comitative constructions and a number of non-phrasal, lexical expressions.

In Section 2, I briefly characterize subject-predicate agreement in Polish and explain exactly what phenomenon I refer to as resolution. Section 3 presents the resolution rules of Corbett 1983, 1991, 2000 and Section 4 provides data which are not properly accounted for by these rules. In Section 5, some related data are discussed. In Section 6, I introduce a new theory of resolution for Polish. Finally, in Section 7, I sum up the discussion and provide final conclusions.

\section{Basic Properties of Polish Agreement}

Polish is an inflectional language, and it has 6 basic grammatical categories ${ }^{1}$ : case (nominative (NOM), genitive (GEN), dative (DAT), accusative (ACC), instrumental (INSTR) and locative (LOC)), person (first (1ST), second (2ND), third (3RD)), number (singular (SG) and plural (PL)), gender (masculine human (M1), masculine animate (M2), masculine inanimate (M3), feminine (FEM), and neuter (NEUT)), aspect (perfect and imperfect), and tense (past, present and future). Polish nouns inflect for case and number, and have inherent person and gender (here, I treat pronouns as

${ }^{1}$ Here I ignore categories such as degree, mood, voice, accentability, postprepositionality, and other possible categories as irrelevant for our discussion. I also exclude the vocative case from this discussion, because it is used exclusively for addressing. 
nouns). Polish verbs have aspect. Perfective verbs occur in past and in future tenses, while imperfective verbs have past and present forms, as well as an analytical future form. Verbs inflect for person and number and, in the past tense, for gender. Polish adjectives inflect for number, gender and case. Prepositions and adverbs do not inflect.

Nominative subjects in Polish agree with predicates with respect to number, person and gender, which is illustrated in (1).

(1) a.

Chłopak

boy.NOM.3RD.SG.M1

'A boy danced.'

tańczył.

danced.3RD.SG.M1

b.

Chłopcy

boys.NOM.3RD.PL.M1

tańczyli.

'The boys danced.'

danced.3RD.PL.M1

c.

Dziewczyna tańczyła.

girl.NOM.3RD.SG.FEM danced.3RD.SG.FEM

'A girl danced.'

d.

Dziewczyny tańczyły.

girls.NOM.3RD.PL.FEM danced.3RD.PL.FEM

'Girls danced.'

The nominative third person masculine human singular noun chtopak 'boy' in (1a) and the plural noun chtopcy 'boys' in (1b) combine with the third person masculine human singular predicate tańczyt 'danced' and the plural predicate tańczyli 'danced', respectively. The third person singular feminine noun dziewczyna 'girl' in (1c) occurs with the third person singular feminine predicate tańczyta, while the plural noun dziewczyny 'girls' in (1d) appears with the feminine plural form of this verb.

It is also well-known that subject-predicate agreement in Polish can be subject to morphosyntax or context / pragmatics. Examples for morphosyntactic subjectpredicate agreement are provided in (2) and (3), and an example for context-driven subject-predicate agreement is given in (4).

\begin{tabular}{|c|c|c|c|c|}
\hline $\begin{array}{l}\text { Ten } \\
\text { this.NOM.SG.M2 } \\
\text { myślał / } \\
\text { thought.SG.M2 / } \\
\text { 'This fat hitch h. }\end{array}$ & $\begin{array}{l}\text { thusty } \\
\text { fat.NOM.SG.M2 } \\
\text { *myślała. } \\
\text { thought.SG.FEM }\end{array}$ & $\begin{array}{l}\text { babsztyl } \\
\text { bitch.NOM.SG.M2 }\end{array}$ & $\begin{array}{l}\text { tylko } \\
\text { only }\end{array}$ & $\begin{array}{l}\mathrm{o} \\
\text { about }\end{array}$ \\
\hline
\end{tabular}


(3)

$\begin{array}{lll}\text { To } & \text { młode } & \text { małżeństwo } \\ \text { this.NOM.SG.NEUT } & \text { young.NOM.SG.NEUT } & \text { married couple.NOM.SG.NEUT } \\ \text { wyemigrowało / } & \text { *yemigrowali } & \text { do USA. } \\ \text { emigrated.SG.NEUT/ } & \text { emigrated.PL.M1 } & \text { to the USA. } \\ \text { 'This young married couple emigrated to the USA.' }\end{array}$

In (2), the nominative singular masculine animate noun babsztyl 'bitch' refers to a female individual. But in spite of the female reference, this noun may only combine with masculine predicates, which is the case of morphosyntactic agreement. The noun matżenstwo 'married couple' in (3) carries the morphosyntactic features nominative singular neuter, but it refers to a group of two people. In spite of the group reference, this noun can only combine with singular predicates. The example in (4) demonstrates the contextual subject-predicate agreement.
$\mathrm{Ci}$
państwo
napisali / *napisało
razem książkę.
these.NOM.PL Mr and Mrs.NOM.SG wrote.PL.M1 / wrote.SG.NEUTR together book
'This man and woman wrote a book together.'

Here, the collective noun państwo 'Mr and Mrs', which is a form of address in Polish, refers to at least one man and one woman. It has thus a group reference. But this noun behaves morphologically like a singular neuter noun, in the sense that it inflects according to this pattern. In (4), we can, however, see that państwo ' $\mathrm{Mr}$ and Mrs' combines with a plural predicate. Hence, we can assume that the subjectpredicate agreement is determined pragmatically here. ${ }^{2}$

There are also cases in Polish where the morphosyntactic and the contextual agreement happen at the same time. This is demonstrated in (5).

(5) a.

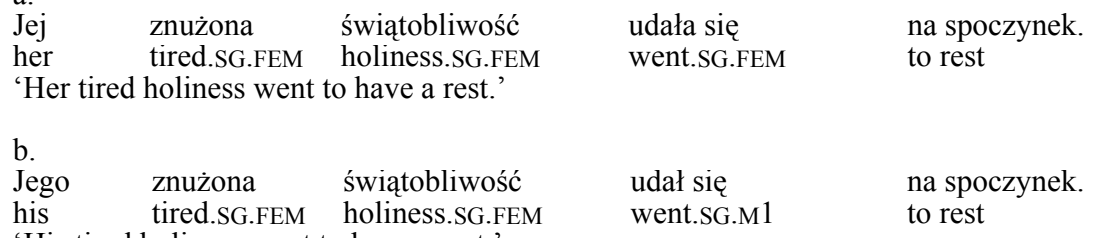

'His tired holiness went to have a rest.'

The title term świqtobliwość 'holiness' in (5) is morphosyntactically feminine, but it can refer both to female and male individuals. Depending on the reference, this

${ }^{2}$ Another interesting observation regarding the noun państwo 'Mr and Mrs' and the subject-predicate agreement considers the person feature. The third person noun państwo 'Mr and Mrs' can, in addition to combining with predicates in the third person form, also combine with second person plural predicates: Państwo napisali / napisaliście razem ksiazke?? (Mr and Mrs.3RD wrote.3RD/wrote.2ND together book) 'Did you write together a book?'. 
noun can combine with feminine or masculine predicates. This is illustrated in $(5 \mathrm{a})$ and (5b), respectively. The subject-predicate agreement can thus be assumed to be context-driven here. But the adjective-noun agreement in (5) is independent of the reference. The adjectives must occur in the feminine form, which implies morphosyntactic agreement. The sentences in (5) thus show that the morphosyntactic and contextual agreement can take place in one sentence at the same time. ${ }^{3}$

The examples (1) through (5) are relatively trivial regarding agreement, because the subjects are syntactically simplex. The predicates and the adjectives in these sentences agree with the simple subject nouns. The situation becomes more complicated when syntactically complex subjects are involved, such as the nominal coordination in (6).

(6)

Dziewczyna i chłopak tańczyli.

girl.NOM.SG.FEM and boy.NOM.SG.M1 danced.PL.M1

'A girl and a boy danced.'

The subject in (6) includes a singular feminine noun and a singular masculine human noun. The predicate, however, has the masculine human plural form. On the basis of the form of the predicate, one can determine the form of the entire subject as being masculine human plural. This form is computed from the forms of the single conjuncts. In this paper, I will refer to this computation of person, number and gender values as resolution, in line with Givon 1970, Pullum and Zwicky 1986, Corbett 1983, 1991, 2000 and others. I thus define resolution as computation of values of the person, number and gender features on the basis of values of the corresponding features carried by all components of a given expression and on the basis of contextual/pragmatic properties of their referents.

\section{Resolution Rules of Corbett 1983, 1991, 2000}

The issue of resolution has been discussed in great detail in Corbett 1983, 1991, 2000 for many Slavic languages, including Polish. On the basis of numerous empirical data, Corbett provides resolution rules for number, gender and person. These rules are presented below.

${ }^{3}$ Derwojedowa - Rudolf 2003 treat expressions such as jej / jego światobliwość 'her / his holiness' as lexical units. They claim that the particular elements of these expressions do not have the status of autonomic words. I argue that these expressions indeed exhibit some degree of collocation, but there is evidence for treating them as syntactically regular expressions. Firstly, they include only free words (as opposed to bound words) which are combined with each other in a regular way. Secondly, the involved words regularly inflect. Thirdly, various syntactic variations are possible within these expressions. An example for the latter has been provided by Derwojedowa - Rudolf 2003 themselves, putting their own claim into question. 
Rules for number resolution according to Corbett $2000: 198$

(i) if there are two conjuncts only, both in the singular, then dual agreement forms will be used;

(ii) in all other cases plural agreement forms will be used.

Both rules apply to languages with a dual, like Slovene, while in languages where there is no dual, like contemporary Polish, the first rule is not required.

Rules for gender resolution for Polish according to Corbett 1991:286, based on Corbett 1983:200

(i) if the subject includes a masculine personal conjunct, the predicate will be in the masculine personal form;

(ii) (optional) if the subject includes the features masculine and personal, whether these are syntactic or semantic, the predicate may be in the masculine personal form;

(iii) (optional) if the subject includes a masculine animate conjunct, the predicate may be in the masculine personal form;

(iv) otherwise the predicate will be in the non-masculine personal form.

Rules for person resolution according to Corbett 1983

(i) if the conjuncts include a first person, first person agreement forms will be used;

(ii) if the conjuncts include a second person, second person agreement forms will be used.

It is important to say that the rules for person resolution are ordered. The second rule operates only if the condition on the operation of the first is not met. If neither rule operates, then third person forms are assigned by default. Thus, if a controller is not marked as a first or a second person, the third person form will be used.

\section{EMPIRICAL Discussion}

In this section, I discuss some Polish data which do not seem to be properly accounted for by the rules provided in Corbett 1983, 1991, 2000. Section 4.1. is devoted to number resolution and Section 4.2. provides data related to gender resolution. Finally, Section 4.3. discusses examples concerning person resolution.

\subsection{NumBer Resolution}

The rules for number resolution predict that if there are two or more singular conjuncts, the plural form is used. This rule, however, does not seem to apply to the sentences in (7) and (8).

(7)

Pracują/ pracuje kobieta i mężczyzna.

work.PL/ work.SG woman.SG and man.SG

'A woman and a man are working.'

(8)

Jedzenie i picie smakowały/smakowało wyśmienicie.

food.SG and drink.SG tasted.PL/ tasted.SG excellent

'The food and the drinks were excellent.' 
In both sentences, the subjects involve two singular nouns and combine with the plural predicates, as expected. But the singular form of the predicates is also grammatical here, which, at first glance, seems to violate the rules for number resolution. However, the singular agreement in (7) and (8) might be considered as an instance of the so called closest conjunct agreement, where the predicate agrees with the conjunct which appears closest to it. By explaining the singular agreement in these sentences via the phenomenon of the closest conjunct agreement, no violation of the rules of Corbett 2000 must be assumed.

In this paper, I adopt the idea of closest conjunct agreement and assume that the rules proposed in Corbett 2000, and more precisely, the second rule, makes the right predictions about Polish and does not need any modification.

\subsection{Gender Resolution}

The first rule for gender resolution for Polish proposed in Corbett 1983, 1991 makes correct predictions about the gender resolution in sentences as in (9a), but seems to make wrong predictions about sentences as in (9b), both taken from Zieniukowa 1979. The abbreviation NMH used in the glosses refers to non-masculine human and covers the following gender forms: masculine animate and inanimate, feminine and neuter, which are syncretic in plural.

(9) a.

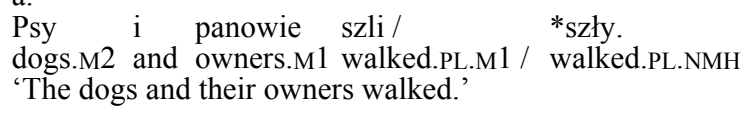

b.

Panowie i psy szli / szły. owners.M1 and dogs.M2 walked.PL.M1 / walked.PL.NMH

'The owners and their dogs walked.'

Both sentences include a masculine human conjunct. The first rule for gender resolution predicts that in this situation, the masculine human form of the predicate must be used. But in (9b), the non-masculine human form seems to be allowed as well. However, (9b) may be considered to be an instance of closest conjunct agreement. Under this assumption, this sentence poses no challenge to the first rule for gender resolution of Corbett. The situation becomes more complicated when considering (10).

(10)

Ten obrzydliwy babochłop i moja żona wybrały / *wybrali się this hideous tomboy.SG.M1 and my wife.SG.FEM went.PL.NMH / went.PL.M1 RM razem na wakacje.

together on holiday

'This hideous tomboy and my wife went on holiday together.'

The coordination in (10) includes a masculine human noun, but the predicate must appear in the non-masculine human form. The non-masculine human form can be explained here by the absence of a male referent. Given this, the first rule for 
gender resolution provided by Corbett must be reformulated, taking into account the gender of the referents of the involved conjuncts. If the masculine human form is used, at least one male individual must be included in the reference of the whole coordination.

The second rule for gender resolution correctly predicts that predicates in sentences as in (11), taken from Zieniukowa 1979: 124-125, can appear in both masculine human and non-masculine human forms.

(11)

Matka i $\quad$ wózek $\quad$ ukazali /
mother.SG.FEM and pram.SG.M3 appeared.PL.M1 / appeared.PL.NMH RM suddenly
'The mother and the pram appeared suddenly.'

The coordination in (11) includes a personal referent and a morphosyntactically masculine (inanimate) conjunct. According to Corbett, this configuration allows for both masculine human and non-masculine human form of the predicate. Laziński 2007 suggests that the masculine human form is chosen in such sentences if the masculine inanimate noun is personalized as agens and participates in a given situation on a par with the feminine noun. Zagórska-Brooks 1973, Zieniukowa 1979, 1981, Dalewska-Greń 1991, Kopcińska 1997 and others have observed that the grammatical number of conjuncts plays an additional role in such cases. If the masculine conjunct occurs in the plural, no masculine human form of the predicate is possible. This is illustrated in (12).

Matka i wózki *ukazali / ukazały się nagle.

mother.SG.FEM and prams.PL.M3 appeared.PL.M1 / appeared.PL.NMH RM suddenly

'The mother and the prams appeared suddenly.'

The second rule also accounts for gender resolution in sentences like (13), taken from Buttler et al. 1971: 250 .

(13)

Dwoje dzieci i i kobieta uratowali / uratowały się z
two children.NEUT and woman.FEM saved.PL.M1 / saved.PL.NMH RM from
płonacego domu.
burning house
'Two children and a woman were saved from the burning house.'

The subject in (13) does not include a morphosyntactically masculine conjunct, but it admits male individuals as referents of the morphosyntactically neuter noun dzieci 'children'. If the subject includes male referents, masculine human agreement on the predicate can appear. Thus, the second rule for gender resolution makes right predictions about sentences like (13). This rule also applies to sentences such as (14), however, making wrong predictions. 
(14)

Ten sopel lodu, $\mathrm{z} \quad$ którym byłem żonaty dwa lata, $\mathrm{i}$ moja

this icicle.M3 with whom was.1ST.M1 married two years and my

aktualna żona wybrały/ *wybrali się razem na wakacje.

current wife.FEM went.PL.NMH / went.PL.M1 RM together on holiday

'This icicle, to whom I was married for two years, and my current wife went on holiday together.'

This example corresponds to (11) by including a personal referent and a morphosyntactically masculine (inanimate) conjunct. However, in contrast to (11), only the non-masculine human form of the predicate is possible here. This phenomenon can be explained by the fact that the subject in (14) refers to female individuals exclusively. The second rule for gender resolution must additionally take this situation into account.

The observation that female reference of the subject rules out the masculine human form of the predicate also applies to the third rule for gender resolution of Corbett. While this rule makes right predictions about gender resolution in sentences like (15), taken from Zieniukowa 1979: 128, it makes wrong predictions about gender resolution in the corresponding sentences such as the example in (16).

Basia i piesek bawili / bawiły się.

Basia.FEM and dog.M2 played.PL.M1/ played.PL.NMH RM

'Basia and the dog played.'

(16)

Ta dziewczyna $\mathrm{i}$ ten babsztyl *wsiedli / wsiadly do autobusu.

this girl.FEM and this bitch.M2 got.PL.M1/got.PL.NMH into bus

'This girl and this bitch got on the bus.'

Both sentences involve a masculine animate conjunct, but the masculine human form of the predicate is possible only in (15). The difference between (15) and (16) concerns the reference of the subjects. In contrast to (15), the referents of the subject in (16) include only female individuals. This fact seems to rule out the possibility of using the masculine human form of the predicate. The third rule for gender resolution of Corbett 1983, 1991 must thus be modified to account for sentences as the one in (16).

\subsection{Person Resolution}

The rules for person resolution proposed in Corbett (1983) require some revision as well. According to these rules, if different persons are conjoint, the first person has priority over the second and the second over the third. This can be seen in the sentences in (17).

(17) a.

Ja i ty pracujemy.

I.1ST and you.2ND work.1ST.PL

'You and I work.' 
b.

Ja i on pracujemy.

I.1ST and he.3RD work.1ST.PL

'He and I work.'

c.

Ty $\mathrm{i}$ on pracujecie.

you.2ND and he.3RD work.2ND.PL

'He and you work.'

The sentences in (18) and (19) demonstrate that the rules for person resolution put forth by Corbett (1983) do not account for all data.

(18) a.

Cała moja rodzina i wszyscy moi znajomi będziemy / będą

whole my family.3RD and all my friends.3RD will.1ST.PL/ will.3RD.PL

świętować razem.

celebrate together

'My whole family and all of my friends will celebrate together.'

b.

Cała moja ekipa remontowa i wszyscy moi sąsiedzi *będziemy /

whole my team.3RD renovation and all my neighbours.3RD will.1ST.PL /

będą świętować koniec remontu.

will.3RD.PL celebrate end renovation

'My whole renovation team and all of my neighbors will celebrate the end of the renovation .'

(19) a.

Cała twoja rodzina i wszyscy twoi znajomi będziecie / będą

whole your family.3RD and all your friends.3RD will.2ND.PL/ will.3RD.PL

świętować razem.

celebrate together

'Your whole family and all of your friends will celebrate together.'

b.

Cała twoja ekipa remontowa i wszyscy twoi sąsiedzi *będziecie / whole your team.3RD renovation and all your neighbours.3RD will.2ND.PL/ będą świętować koniec remontu.

will.3RD.PL celebrate end renovation

'Your whole renovation team and all of your neighbors will celebrate the end of the renovation.'

Although the coordination in (18a) includes only third person nouns, the person value of the predicate can be both first and third. Similarly, the subject in (19a) includes only third person nouns, but the predicate can occur in both the second and third person forms. The reason for this is the presence of the speaker and the addressee, respectively, in the set of referents. This can be attested by the corresponding examples in (18b) and (19b), where no speaker or addressee is available and, consequently, only the third person form of the predicate is grammatical.

In conclusion, the rules for person resolution of Corbett (1983) must be reformulated in order to account for data such as the examples provided in (18a) and (19a). 


\section{Related Data}

In this section, I will demonstrate that there is a correspondence between person, number and gender resolution in nominal coordination and comitative constructions, title terms and personal plural pronouns.

\subsection{Comitative Constructions}

The issue of person, number and gender resolution has previously been discussed in the linguistic literature with reference to nominal coordination. There are, however, expressions, where the same pattern with respect to person, number and gender resolution can be observed as in nominal coordination. These expressions are referred to as comitative constructions, and are illustrated by the Polish example in (20).

(20)

Jan $\mathrm{z}$ Marią wyjechał / wyjechali.

Jan.3RD.NOM.SG.M1 with Maria.3RD.INSTR.SG.FEM left.3RD.SG.M1 / left.3RD.PL.M1

'Jan left with Maria. / Jan and Maria left.'

The subject in (20) contains a nominative singular masculine human noun and an instrumental singular feminine noun connected by the preposition $z$ 'with'. This expression can combine with a singular predicate which agrees with the nominative noun, or it can combine with a plural masculine human predicate. Only the second case is relevant to our discussion.

It has been observed in many approaches to comitative constructions with plural agreement on the predicate in Slavic and other languages that these expressions show the same properties with respect to the instantiation of person, number and gender values as ordinary coordination, cf. Dyła 1988, McNally 1989, Vassilieva Larson 2005, Feldman 2001, Ionin - Matushansky 2002 and Trawiński 2005a. I propose to treat these constructions as subject to the same resolution rules as ordinary coordination.

\subsection{Title Terms}

Comitative constructions and nominal coordination are syntactically complex expressions in which resolution takes place. There are, however, non-phrasal, lexical expressions in Polish where an internal gender resolution can be observed. One kind of such expressions are the morphosyntactically feminine title terms such as siwiqtobliwośc 'holiness', as provided in (5). Nouns of this kind refer to male or female individuals and trigger mixed agreement. The instantiation of the gender value of these nominals proceeds word-internally and incorporates the natural gender of their referents. Other examples of Polish morphosyntactically feminine title terms which are able to denote male and female individuals, being subject to mixed agreement, are mość 'majesty', magnificencja 'magnificence' and wysokość 'highness'.

I propose that the rules for gender resolution in addition to covering coordination and comitative constructions take title terms into account. 


\subsection{Plural Pronouns}

Another instance of non-phrasal expressions to which the phenomenon of gender resolution applies are Polish first and second person personal plural pronouns. The value of their gender depends on the natural gender of the individuals included in the set of referents of these pronouns. This is illustrated in (21) and (22). If the set of referents of the first person plural pronoun $m y$ 'we' in (21) includes a male individual, the masculine human form of the predicate is used. If there are no male individuals, the non-masculine human form is used.

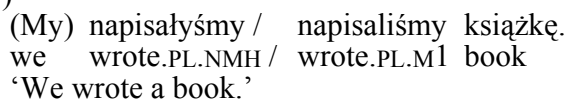

The same observation can be made in (22), involving the second person plural pronoun wy 'you'. If there is a male individual, the masculine human form on the predicate is used, otherwise the non-masculine human form is chosen.

(Wy) napisałyście / napisaliście książkę.

you wrote.PL.NMH / wrote.PL.Ml book

'You wrote a book.'

I propose to reformulate the rules for gender resolution in such a way that they also account for plural pronouns.

\section{The Theory of Resolution for Polish}

In the previous sections, I have demonstrated that person, number and gender resolution in Polish is a phenomenon pertaining to the morphosyntactic and pragmatic domains, on the one hand, and to syntactically complex expressions as well as to non-phrasal expressions, on the other hand. In this section, I will formulate a theory of agreement and resolution which uniformly accounts for these phenomena.

\subsection{Morphosyntactic Agreement Features and Phi-Features}

To properly account for all agreement phenomena, including mixed agreement, I adopt the idea proposed in Czuba - Przepiórkowski 1995, based on Kathol 1999 and elaborated for Polish in Przepiórkowski et al. 2002. According to this idea, nominal expressions contain information about their number and gender at two representation levels: at the morphosyntactic and at the semantic level. In my proposal, the agreement features specified at the semantic level include person, number and gender, i.e., the traditional Phi-features. The agreement between particular expressions in the sentence can then be treated by means of their morphosyntactic agreement features, by means of their Phi-features, or both.

Having two different sets of agreement features makes it possible to account for the agreement mismatch in sentences involving title terms such as wysokość 'highness' and światobliwość 'holiness'. I assume following Przepiórkowski et al. 2002 
that in Polish, agreement between an attributive adjective and a noun should be described in terms of morphosyntactic agreement, whereas agreement between a nominative subject and a predicate should be treated in terms of context-driven agreement. In my analysis, the context-driven agreement will be described using Phi-features. ${ }^{4}$

\subsection{Inherent versus Resolved Phi-Features Values}

To account for person, number and gender resolution, I propose treating the values of the Phi-features in terms of inherent versus resolved values. The values of the features person, number and gender of the majority of Polish nouns will be specified in the lexicon, i.e., they will be treated as inherent values. For morphosyntactically feminine title terms as well as for first and second person plural pronouns, I assume that the values of their person and number features are specified in the lexicon as well. The value of their gender feature will, however, be resolved. As for comitative constructions as well as nominal coordination, the values of all their Phifeatures will require resolution. The resolution rules will apply to all objects whose Phi-features' values are to be resolved.

The values of the Phi-features which must be resolved are licensed by virtue of three grammar principles: The principle for number resolution, The principle for gender resolution, and The principle for person resolution. These principles are based on the rules for number, person and gender resolution proposed in Corbett 1983a, 1991, 2000.

The principle for number resolution ensures that all expressions whose Phi-feature number is specified as to be resolved are plural. Given the assumptions in the previous sections, this principle will apply to nominal coordination and comitative constructions.

The principle for number resolution

If the value of the Phi-feature number must be resolved, this value will be plural.

The principle for gender resolution operates on the morphosyntactic as well as the contextual representation. In addition to the rules for gender resolution of Corbett, this principle accounts for internal gender resolution in title terms and plural pronouns.

The principle for gender resolution

If the value of the Phi-feature gender must be resolved, then

4 Assuming two bundles of agreement features, morphosyntactic and Phi-features, will also allow us to account for agreement mismatch phenomena in other languages, such as those described in Kathol 1999 for Spanish, in Wechsler - Zlatić 2001 for Serbo-Croatian, in Osenova 2003 for Bulgarian, or in Rosen 2007 for Czech. 
(i) if a (syntactically complex) expression includes a masculine human component and at least one of the referents is male, the entire expression will be masculine human;

(ii) if the denotation of a word includes a male referent, the gender value of this word will be masculine human;

(iii) if a singular word refers to a female individual, the gender value of this word will be female;

(iv) if an expression refers to female individuals only, this expression will be non-masculine human;

(v) if there is no morphosyntactically singular masculine animate or masculine inanimate component, the entire expression will be non-masculine human;

(vi) otherwise, the masculine human or non-masculine human forms may be used.

The five clauses account for gender resolution in (i) nominal coordination and comitative expressions involving a masculine human component and a component referring to a male individual; (ii) plural pronouns and title terms involving a male referent; (iii) title terms referring to female individuals; (iv) nominal coordination and comitative expressions referring to female individuals; and, finally, (v) nominal coordination and comitative expressions without a singular masculine animate or inanimate component.

The principle for person resolution applies to contextual and morphosyntactic representation levels as well.

The principle for person resolution

If the value of the Phi-feature person must be resolved, then

(i) if an expression includes a first person component, the person value of this expression will be first;

(ii) if an expression includes a second person component and no first person component, the person value of this expression will be second;

(iii) if an expression does not include a first or second person component and there is no speaker or addressee in the set of referents of this expression, the person value of this expression will be third.

By virtue of The principle for person resolution, morphosyntactic and context-driven person resolution in Polish comitative constructions as well as nominal coordination can be accounted for.

\section{Summary and Conclusions}

In this paper, I have presented the resolution rules of Corbett 1983, 1991, 2000, discussed a number of Polish data and demonstrated that these rules require some revision for Polish. I have also indicated that not only nominal coordination is subject 
to resolution in Polish, but also comitative constructions, title terms and first and second person plural personal pronouns. I have formulated a theory of resolution for Polish which uniformly and modularly accounts for all these kinds of expressions. It is worth considering whether other types of expressions can be accounted for by the proposed resolution principles as well. The possible candidates are prepositionpronoun contractions, such as nań 'at+pronoun' or dlan' 'for+pronoun' (cf. Trawiński 2005b), and nouns with mixed gender, such as oferma 'milksop' or tamaga 'weakling' (cf. Dalewska-Gren 1991). It would be also desirable to determine locality condictions for agreement for Polish and describe their interaction with the resolution principles proposed in this paper.

\section{References}

Buttler et al. 1971: D. Buttler - H. Kurkowska - H. Satkiewicz, Kultura języka polskiego,

Corbett 1983:

Corbett 1991:

Corbett 2000: Warszawa

Czuba - Przepiórkowski 1995: K. Czuba - A. Przepiórkowski, Agreement and Case AssignG. G. Corbett, Hierarchies, Targets and Controllers: Agreement Patterns in Slavic, University Park G. G. Corbett, Gender, Cambridge

G. G. Corbett, Number, Cambridge ment in Polish: An Attempt at a Unified Account, Technical Report 783, Warszawa

Dalewska-Greń 1991: H. Dalewska-Greń, Selektywna kategoria rodzaju w języku polskim i serbsko-chorwackim, Warszawa

Derwojedowa - Rudolf 2003: M. Derwojedowa - M. Rudolf, Czy Burkina to dziewczyna i co o tym sądzą Ich Królewskie Mości? Poradnik językowy 5, 39-49

Dyła 1988: S. Dyła, Quasi-Comitative Coordination in Polish, Linguistics 26, 383-414

Feldman 2001: $\quad$ A. Feldman, Comitative and Plural Pronoun Constructions, in: Proceedings of the 17th Annual Meeting of the Israel Association of Theoretical Linguistics, 2001, http://linguistics.huji.ac.il/IATL/17/

Givón 1970: T. Givón, The Resolution of Gender Conflicts in Bantu Conjunction: When Syntax and Semantics Clash, in: Papers from the Sixth Regional Meeting, Chicago Linguistic Society, Chicago, 250-261

Ionin - Matushansky 2002: T. Ionin - O. Matushansky, DPs with a Twist: A Unified Analysis of Russian Comitatives, in: W. Browne, J. Kim, B.H. Partee, R.A. Rothstein (eds.), Formal Approaches to Slavic Linguistics 11, The Amherst Meeting 2002, Ann Arbor

Kathol 1999:

A. Kathol, Agreement and the Syntax-Morphology Interface in HPSG, in: R. Levine, G. Green (eds.), Studies in Contemporary Phrase Structure Grammar, Cambridge - New York, 209-260

Kopcińska 1997: D. Kopcińska, Structuralny opis składniowy zdań z podmiotem mianownikiem we współczesnej polszczyźnie, Warszawa

Łaziński 2007: M. Łaziński, Wino, kobieta i śpiew. Podmiot złożony osobowo-rzeczowy w polszczyźnie, Biuletyn Polskiego Towarzystwa Językoznawczego $63,73-80$

McNally 1989: $\quad$ L. McNally, Comitative Coordination: A Case Study in Group Formation, Natural Language and Linguistic Theory 11,347-379

Przepiórkowski et al. 2002: A. Przepiórkowski - A. Kupść - M. Marciniak - A. Mykowiecka, Formalny opis jezyka polskiego: Teoria i implementacja, Warszawa 
Pullum - Zwicky 1986: G. K. Pullum - A. M. Zwicky, Phonological Resolution of Syntactic Feature Conflict, Language 62, 751-773

Trawiński 2005a: $\quad$ B. Trawiński, Plural Comitative Constructions in: Polish, in The Proceedings of the 12th International Conference on HPSG, Stanford, 375-395

Trawiński 2005b: $\quad$ B. Trawiński, Preposition-Pronoun Contraction in Polish, in: The Proceedings of the Second ACL-SIGSEM Workshop on the Linguistic Dimensions of Prepositions and their Use in Computational Linguistics Formalisms and Applications, Colchester, 20-29

Vassilieva - Larson 2005: M. B. Vassilieva - R. K. Larson, The Semantics of the Plural Pronoun Construction, Natural Language Semantics 13, 101-124

Wechsler - Zlatić 2001: S. Wechsler - L. Zlatić, A Theory of Agreement and its Application to Serbo-Croatian, Language 76/4, 799-832

Zagórska-Brooks 1973: M. Zagórska-Brooks, Rola liczby i rodzaju przy zgodzie niektórych podmiotów z orzeczeniem, in: L. Mateja (ed.), American Contributions to the Seventh International Congress of Slavists, The Hague, 59-66

Zieniukowa 1979: J. Zieniukowa, Składnia zgody w zdaniach z podmiotem szeregowym we współczesnej polszczyźnie, Slavia Occidentalis 36, 117-129

Zieniukowa 1981: J. Zieniukowa, Rodzaj męski osobowy we współczesnych językach zachodniosłowiańskich, Wrocław

A b stra ct: Theoretical and Empirical Aspects of Person, Number and Gender Resolution in Polish. In this paper, I discuss morphosyntactic and contextual aspects of person, number and gender resolution in Polish, and argue that the rules proposed by Corbett require some revision in light of a number of empirical facts. I also point out that besides syntactically complex expressions, such as coordination and comitative constructions, there are non-phrasal expressions where gender resolution occurs. These expressions include morphosyntactically feminine title terms and first and second person personal plural pronouns. I suggest a revision of Corbett's resolution rules in a way that allows us to account for all these phenomena.

K e y w o r s : agreement, person, number and gender resolution, Polish

Beata Trawiński

Institut für Slawistik der Universität Wien

Universitätscampus AAKH, Hof 3

Spitalgasse 2, 1090 Wien, Österreich

beata.trawinski@univie.ac.at 
